\title{
UPAYA MENINGKATKAN KEMAMPUAN MENDENGARKAN BAHASA INGGRIS MELALUI METODE PEMBELAJARAN AUDIO VISUAL PADA SISWA KELAS VIII SMPN 2 DAWARBLANDONG TAHUN PELAJARAN 2017/2018
}

\author{
Suwanto \\ SMPN 2 Dawarblandong Mojokerto \\ suwantodwb@gmail.com
}

\begin{abstract}
ABSTRAK
Penelitian ini dilaksanakan di SMP N 2 Dawarblandong di Kelas VIII yang kemampuan siswanya untuk materi mendengarkan Bahasa Inggris cukup rendah. Sedangkan tujuan dari penelitian ini adalah untuk mengetahui peningkatan prestasi belajar siswa setelah diterapkannya Model Pembelajaran Audio Visual, serta ingin mengetahui pengaruh motivasi belajar siswa setelah diterapkan Model Pembelajaran Audio Visual. Tujuan Akhir dari penulisan penelitian tindakan kelas ini adalah untuk mengetahui apakah model pembelajaran Audio-Visual dapat meningkatkan aktivitas dan prestasi belajar siswa. Metode pengumpulan datanya adalah observasi dan tes prestasi belajar. Metode analisis datanya adalah deskriptif baik untuk data kualitatif maupun untuk data kuantitatif. Hasil yang diperoleh dari penelitian ini adalah AudioVisual dapat meningkatkan aktivitas dan prestasi belajar siswa. Ini terbukti dari hasil yang diperoleh pada Siklus I adalah 6,3 untuk prestasi belajar. Dari Siklus I ke Siklus II naik menjadi 7,9 untuk prestasi belajar. Kesimpulan yang diperoleh dari penelitian ini adalah model pembelajaran Audio-Visual dapat meningkatkan prestasi belajar.
\end{abstract}

Kata Kunci: Bahasa Inggris, Metode Pembelajaran Audio Visual

\section{ABSTRACT}

The research was conducted at SMP N 2 Dawarblandong in Class VIII whose students' ability to listen to English is quite low. While the purpose of this study is to determine the improvement of student achievement after the implementation of Audio Visual Learning Model, and want to know the effect of student learning motivation after applied Audio Visual Learning Model. The ultimate goal of writing this classroom action research is to find out whether the Audio-Visual learning model can improve student activity and achievement. The method of data collection is observation and test of learning achievement. Data analysis methods are descriptive for both qualitative and quantitative data. The result obtained from this research is Audio-Visual can increase student activity and achievement. This is evident from the results obtained in Cycle I is 6.3 for learning achievement. From Cycle I to Cycle II rose to 7.9 for learning achievement. The conclusion obtained from this research is Audio-Visual learning model can improve learning achievement.

Keywords: English, Audio Visual Learning Method

\section{PENDAHULUAN}

Didalam kehidupan kita, Bahasa adalah alat komunikasi yang paling signifikan didalam komunikasi. Komunikasi bisa dilakukan dengan berbicara, menulis dan lain sebagainya. Dengan bahasa kita bisa mengungkapkan perasaan, ide-ide, dan pikirin kita kepada seseorang secara langsung, dengan selembar kertas atau dengan gerakan tubuh. 
Bahasa merupakan suatu alat yang digunakan oleh manusia untuk berkomunikasi dalam masyarakat. Bahasa itu sangat penting untuk semua orang didunia ini, dengan bahasa mereka mampu menjalin hubungan dengan orang lain yang berasal dari latarbelakang bahasa yang berbeda. Misalnya bahasa inggris, bahasa inggris adalah sebuah bahasa internasional. Dimana bahasa ini digunakan sebagai alat komunikasi dalam forum-forum internasional. Sekarang ini, banyak Negara didunia ini menggunakannya sebagai alat komunikasi. Oleh karena itu bahasa inggris menjadi mata pelajaran yang sangat penting yang harus diajarkan sejak dini sampai dengan perguruan tinggi seperti SD, SMP, SMA dan Universitas.

Salah satu tujuan pembelaran di SMP adalah mengembangkan kemampuan mendengarkan dalam bahasa ingris. Tujuan tersebut dalam kurikulum Bebasis Kompetensi dinyatakan dengan istilah Kompetensi Dasar. Kompetensi Dasar Pembelajaran Bahasa Inggris di SMP/Mts adalah "memahami makna dalam percakapan transaksional dan interpersonal sangat sederhana untuk berinteraksi dengan lingkungan terdekat".

Ketika kita mempelajari bahasa inggris, kita mengenal empat komponen bahasa, seperti: mendengarkan, membaca, menulis, dan berbicara, dimana keempat komponen ini menjadi faktor utama dalam mengajarkan bahasa inggris sebagai bahasa asing. Komponen komponen ini akan mengembangkan kemampuan komunikasi siswa baik secara lisan atau tulisan.

Listening skill, salah satu kemampuan menerima, adalah sebuah tehnik komunikasi dimana pendengar bisa mengerti, menginterpretasikan dan mengevaluasi apa yang mereka dengar. Kemampuan untuk mendengarkan secara aktif dapat meningkatkan hubungan pribadi melalui mengurangi konflik, memperkuat kerjasama ,mengembangkan pemahaman.

Listening adalah salah satu komponen bahasa yang masih menjadi kendala bagi siswa untuk dipelajari. Kita bisa mengetahui dari pencapaian siswa. Nilai yang mereka dapatkan masih rendah jika dibandingkan dengan komponenkomponen bahasa lain seperti reading dan writing.

Komunikasi akan berjalan lebih baik jika pendengar bisa merespon apa yang pembicara bicarakan. Namun, kebanyakan siswa masih memiliki kesulitan dalam mendengar karena adanya perbedaan dialek. Perbedaan tersebut tidak hanya dari segi pengucapan tetapi juga dari kebudayan. Secara gramatikal juga bisa mengakibatkan misunderstanding antara pembicara dan pendengar.

Rendahnya kemampuan menyimak siswa dalam bahasa inggris dipengaruhi oleh berbagai faktor antara lain : minimnya pengetahuan 
bahasa inggris siswa, masih minimnya pembendaharaan kosakakata siswa, kurangnya latihan komunikasi berbahasa inggris siswa dalam kehidupan sehari-hari, rendahnya aktivitas memahami bahasa inggris siswa, rendahnya kualitas tugas-tugas siswa, dan kurang tepatnya tehnik yang digunakan guru.

Di antara sekian faktor penyebab rendahnya keterampilan siswa memahami dalam bahasa Inggris teknik pembelajaran yang kurang tepat merupakan faktor yang paling dominan. Guru secara terus menerus memperkenalkan pola-pola dan ungkapan bahasa Inggris tanpa melalui konteks atau situsi yang tepat, dan tidak diikuti oleh latihan dan penerapan atau praktek mendengarkan. Kegiatan interaksi antar siswa sangat kurang. Oleh karena itu peningkatan keterampilan berbicara dalam bahasa Inggris tidak optimal.

Didalam mengatasi masalah tersebut, para guru harus tetap berusaha mencari cara agar bagaimana masalah itu bisa teratasi. Guru harus mampu menggunakan beberapa metode pembelajaran khususnya dalam mengajarkan listening. Dan salah satu tehnik yang bisa diterapkan untuk meningkatkan kemampuan mendengar siswa adalah melalui Audio-Visual. Audio-lingual or Audio-visual adalah metode yang sangat menarik dalam proses pembelajaran. Oleh karena itu metode ini bertujuan agar pelajar atau siswa mampu memahami target bahasa, berbicara dengan pengucapan yang dapat diterima dan benar secara gramatikal, dan mampu memahami materi yang dipresentasikan.

Suleiman (1985:11) mengatakan bahwa Audio-visual or Audio-lingual adalah media yang dapat dilihat dan didengar dalam melaksanakan komunikasi. Salah satu Audio-lingual method adalah video. Video bisa diputar sesuai dengan materi yang dibutuhkan. Itu bisa digunakan untuk menonton film. Berdasarkan film tersebut dapat meningkatkan pemahaman siswa.

Berdasarkan latarbelakang diatas dan mengetahui kelemahan siswa dalam mempelajari listening dan kurangnya kemampuan siswa terhadap pemahaman listening. Maka penulis focus untuk mengajar listening melalui Audio-Visual bagi siswa SMP N 2 Dawarblandong kelas 8 dengan menggunakan DVD (Digital Video Disc).

\section{METODE PENELITIAN}

\section{Setting penelitian}

Penelitian ini dilakukan di kelas 8 SMPN 2 Dawarblandong yang dipilih berdasarkan hasil observasi kelas dan wawancara dengan guru bahasa Inggris di kelas itu dapat disimpulkan bahwa keterampilan siswa menyimak dalam bahasa inggris masih rendah. Hal ini disebabkan karena guru tidak menggunakan teknik yang memadai, terbatasnya buku yang ada di sekolah dan perlengkapan media yang masih kurang. 
Penelitian ini dilakukan pada

pelaksanaan penelitian ini dapat bulan oktober sebagai gambaran dari dilihat pada tabel berikut:

Tabel 1. Jadwal Penelitian

\begin{tabular}{|c|l|c|c|c|c|}
\hline \multirow{2}{*}{ No Kegiatan } & \multicolumn{5}{|c|}{ Oktober } \\
\cline { 3 - 6 } & & $\mathbf{1}$ & $\mathbf{2}$ & $\mathbf{3}$ & $\mathbf{4}$ \\
\hline 1 & Penyusunan proposal dan perencanaan tindakan I & $\mathrm{V}$ & & & \\
\hline 2 & Pelaksanaan tindakan I & $\mathrm{V}$ & & & \\
\hline 3 & Pengamatan/pengumpulan data I & & $\mathrm{V}$ & & \\
\hline 4 & Refleksi I & & $\mathrm{V}$ & & \\
\hline 5 & Perencanaan tindakan II & & & $\mathrm{V}$ & \\
\hline 6 & Pelaksanaan tindakan II & & & $\mathrm{V}$ & \\
\hline 7 & Pengamatan/ pengumpulan data II & & & & $\mathrm{V}$ \\
\hline 8 & Refleksi II & & & & $\mathrm{V}$ \\
\hline 9 & Penulisan laporan/ penjilidan & & & $\mathrm{V}$ \\
\hline
\end{tabular}

\section{Subjek Penelitian}

Yang dijadikan subjek dalam penelitian ini adalah semua siswa kelas 8 SMPN 2 Dawarblandong. Seluruh kelas berjumlah 27 orang, yang terdiri dari 11 orang siswa perempuan dan 16 orang siswa lakilaki. Dua orang siswa perempuan mempunyai kemampuan yang relatif baik dalam mendengarkan bahasa Inggris, enam orang mempunyai kemampuan sedang, dan tiga orang mempunyai kemampuan yang sangat lemah. Dua orang siswa laki laki mempunyai kemampuan yang relatif baik dalam menyimak bahasa Inggris. Lima orang mempunyai kemampuan sedang, dan sembilan orang sangat tidak mampu mendengarkan dalam berbahasa Inggris.

\section{Sumber Data}

Data hasil penelitian ini bersumber dari siswa dan guru. Data dari siswa adalah hasil test, baik test awal maupun test akhir yang dapat diamati langsung oleh peneliti, dan aktivitas dalam proses pembelajaran. Data dari guru adalah hasil observasi yang dilakukan peneliti saat proses belajar mengajar sedang berlangsung sebagai data tambahan dalan penelitian ini.

\section{Teknik dan Alat Pengumpulan Data}

1. Teknik pengumpulan data

Teknik pengumpulan data yang digunakan dalam penelitian ini adalah tes dan lembar observasi. Tes diberikan kepada siswa untuk mendapatkan pemahaman siswa dalam mendengar bahasa inggris. Lembar Pengamatan digunakan untuk mencatat informasi dari semua kegiatan yang sedang berlangsung. Lembar pengamatan terdiri dari aktivitas siswa, waktu, respon siswa, situasi kelas, dan catatan lainnya yang terjadi saat prosses tindakan berlangsung

2. Alat Pengumpulan Data

Alat yang dipakai untuk mengumpulkan data adalah hasil 
dari test, questionnaire dan lembar observasi.

\section{Analisis Data}

Data yang diperoleh dalam setiap tindakan akan dianalisis secara kuantitatif dan kualitatif untuk mengetahui hasil akhir dari suatu tindakan. Data kualitatip hasil belajar siswa akan dianalisis secara deskriptif dengan cara mencari nilai rata-rata keberhasilan siswa baik dalam pre tes dan post tes. Data hasil evaluasi akan dianalisis menggunakan analisis deskriptif dengan cara mencari nilai rata-rata keberhasilan siswa baik dalam pre tes dan post tes. Yaitu dengan menggunakan langkahlangkah berikut:

1. Nilai dari setiap siswa menjawab test dalam setiap pertemuan.

2. Data dihitung dengan rumus sebagai berikut:

$$
\overline{\mathrm{x}}=\frac{\sum \mathrm{x}}{\mathrm{N}}
$$

Dimana:

$$
\begin{aligned}
X= & \text { Nilai rata-rata yang dicapai } \\
& \text { siswa pada test. } \\
\Sigma X= & \text { Jumlah keseluruhan nilai. } \\
\mathrm{N}= & \text { Jumlah siswa }
\end{aligned}
$$

Sedangkan, Data kualitatif yang didapat melalui lembar observasi dianalisis sehingga dapat memberikan gambaran tentang tingkat pemahaman terhadap pelajaran, sikap atau pandangan siswa terhadap metode belajar yang diterapkan, aktivitas siswa dalam mengikuti pelajaran, perhatian, antusias dalam belajar, kepercayaan diri, motivasi belajar, dan yang sejenisnya dianalisis secara kualitatif.

\section{Prosedur Penelitian}

Penelitian ini dilakukan dengan menggunakan metode penelitian tindakan kelas (PTK). Ada empat tahapan yang lazim dilalui dalam penelitian tindakan kelas ini yaitu (1) Perencanaan, (2) Pelaksanaan, (3) Pengamatan, dan (4) Refleksi (Arikunto, 2007: 11). Seperti pada model di bawah ini:

Gambar 1. Alur Penelitian Tindakan Kelas

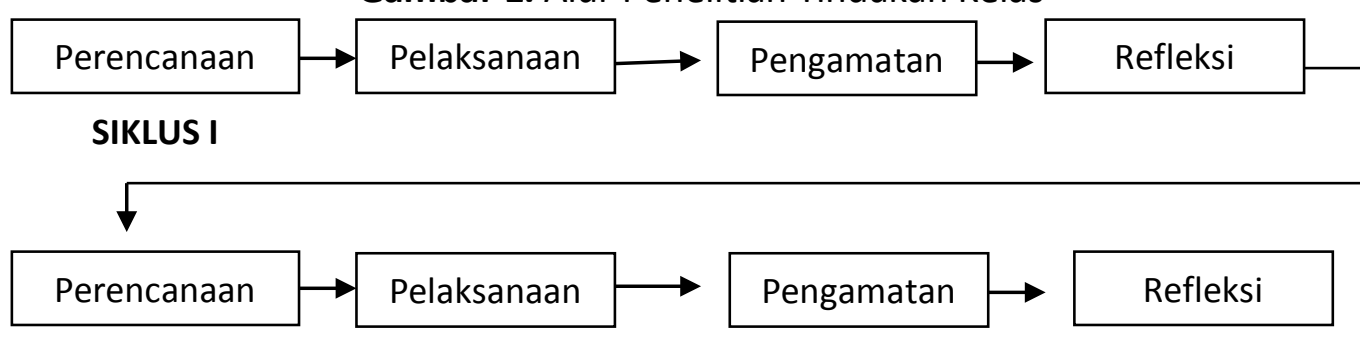

SIKLUS II

Keempat langkah dengan dua siklus di atas dilakukan untuk meningkatkan kemampuan siswa dalam mendengarkan bahasa inggris. akan dipaparkan secara rinci berikut ini.

\section{Perencanaan}

Tahapan ini peneliti menyusun Secara jelas keempat langkah di atas dan merancang tindakan yang akan dilaksanakan untuk meningkatkan 
kemampuan pemahaman listening siswa dan motivasi belajar siswa yang rendah. Berdasarkan atas tes awal dan observasi yang dilakukan, ratarata siswa hanya 5,7 dan dengan semangat dan motivasi belajar yang rendah. Tindakan yang diberikan terhadap siswa hanya berlangsung dalam 2 siklus dalam kurun waktu 12 $x 40$ menit.

Rencana tindakan yang dilaksanakan dalam tahapan ini adalah rancangan pembelajaran yang dikembangkan berdasarkan masalah yang ditemukan dan metode belajar yang dipakai yaitu Audio-Visual untuk memecahkan masalah rendahnya pemahaman dan motivasi belajar siswa.

\section{Pelaksanaan}

Pada langkah ini peneliti melakukan langkah-langkah pembelajaran dengan menerapkan tehnik Audio-Visual sesuai dengan rancangan pembelajaran yang telah dipersiapkan pada langkah pertama.

Dalam perlakuan tindakan melalui penerapan Audio-Visual peneliti melaksanakan kegiatan pembelajaran sesuai dengan rancangan pembelajaran yang disusun. Siswa dibimbing melalui langkah-langkah untuk meningkatkan pemahamannya secara efektif dan efisien dan meningkatkan kinerja memori dalam memahami isi percakapan.

Langkah pertama, Video pertama dengan topic "Always remember to say please" diputarkan kepada siswa dengan memberikan beberapa brainstorming untuk meningkatkan keinginan minat belajar siswa. Setelah video tersebut diputarkan selama 2 kali, kemudian siswa disuruh untuk menjawab beberapa pertanyaan yang bersifat umum sesuai dengan video yang diputarkan. Kemudian penulis mangjak siswa untuk mebahas setiap jawaban dari setiap pertanyaan yang diberikan.

Setelah pembahasan itu selesai, kemudian video kedua dengan topik "Cheers... hicccuupp" diputarkan selama 2 kali. Kemudian siswa disuruh menjawab pertanyaan yang diberikan oleh penyaji secara lisan namun pertanyaan yang diberikan kali ini lebih mendetail berhubungan dengan video yang diputarkan.

Langkah selajutnya, siswa diputarkan video dengan topik "Long time no see and Jeffry doesn't live here" selama dua kali. Setelah video tersebut selesai diputarkan, kemudian siswa diberikaan multiple choice test dan siswa diberikan kesempatan untuk menjawab pertanyaan tersebut.

Setelah semua jawaban siswa terkumpulkan, kemudian siswa diberiakan naskah dari video pertama sampai video terakhir, kemudian siswa disuruh untuk menampilkan (perform) setiap video yang diputarkan sebelumnya di depan kelas.

Langkah-langkah di atas merupakan intisari dari perlakuan yang diberikan kepada siswa untuk 
meningkatkan pemahamannya dalam mendengarkan bahasa inggris. sehingga, hasil belajar siswa dengan menggunakan tehnik Audio-Visual dapat diharapkan lebih memuaskan dan dapat meningkatkan kemampuan mendengarkan siswa.

\section{Pengamatan}

Pengamatan dilakukan pada waktu tindakan sedang berjalan. Peneliti mencatat semua hal yang diperlukan dan terjadi selama pelaksanaan tindakan berlangsung.
Pengumpulan data dilakukan dengan menggunakan tes dan lembar pengamatan yang telah disusun sebelumnya. Data yang dikumpulkan adalah dalam bentuk data kuantitatif dari hasil tes siswa dan data yang bersifat kualitatif yang berasal dari lembar pengamatan. Hal-hal lain yang penting yang berhuungan dengan tindakan juga dicatat dalah langkah ini. Format pengamatan saat proses tindakan sedang berlangsung sebagai berikut.

Tabel 2. Format Proses Pengamatan

\begin{tabular}{|c|l|c|c|c|}
\hline No & \multicolumn{1}{|c|}{ Hal-hal yang diamati } & Baik & Cukup & Kurang \\
\hline 1. & Perhatian siswa saat menerima perintah & & & \\
\hline 2. & Keseriusan siswa dalam proses tindakan & & & \\
\hline 3. & Tanggapan siswa & & & \\
\hline 4. & Situasi pembelajaran & & & \\
\hline 5. & Efektivitas media pembelajaran & & & \\
\hline 6. & Respon siswa dalam menerima perintah & & & \\
\hline 7. & Ketepatan waktu & & & \\
\hline 8. & Motivasi siswa terhadap pelajaran & & & \\
\hline 9. & Perubahan sikap & & & \\
\hline 10. & Kepercayaan diri & & & \\
\hline 11. & Peningkatan keterampilan & & & \\
\hline
\end{tabular}

\section{Refleksi}

Tahapan ini dimaksudkan untuk mengkaji secara menyeluruh tindakan yang telah dilakukan, berdasarkan data yang telah terkumpul pada langkah sebelumnya. Dan mencari kesulitan yang dialami oleh siswa dan guru dalam proses tindakan yang telah dilakukan. Siswa diajak diskusi pada setiap siklus untuk menanyakan kesulitan-kesulitan yang mereka alami. Sedangkan guru merenungkan kembali peristiwa yang sudah lampau ketika proses tindakan berlangsung.
Semua data yang didapat dianalisis dan dievaluasi untuk menyempurnakan tindakan pada siklus berikutnya atau perlu tidaknya perlakuan yang diberikan kepada siswa dilanjutkan.

\section{HASIL PENELITIAN}

Pada Bab IV ini penulis sampaikan data yang diperoleh dari penelitian tindakan ini secara rinci berdasarkan penelitian yang dilakukan di SMPN 2 Dawarblandong. Sebelum menyampaikan hasil-hasil penelitian 
ada baiknya dilihat dahulu pendapat para ahli pendidikan berikut: dalam menyampaikan hasil penelitian dan pembahasan, perlu menyajikan uraian masing-masing siklus dengan data lengkap mulai dari perencanaan, pelaksanaan, pengamatan dan refleksi yang berisi penjelasan tentang aspek keberhasilan dan kelemahan yang terjadi. Perlu ditambahkan hal yang mendasar, yaitu hasil pembahasan (kemajuan) pada diri siswa, lingkungan, guru, motivasi dan aktivits belajar, situasi kelas dan hasil belajar, kemukakan grafik dan tabel hasil analisis data yang menunjukkan perubahan yang terjadi disertai pembahasan secara sistimatis dan jelas (Suharsimi Arikunto, Suhardjono, Supardi, 2006: 83).

Dari cuplikan di atas jelaslah apa yang harus dipaparkan dalam Bab ini yaitu menulis lengkap mulai dari apa yang dibuat sesuai perencanaan, hasilnya apa, bagaimana pelaksanaanya, apa yang telah dicapai, sampai pada refleksi. Oleh karenanya pembicaraan pada bagian ini dimulai dengan apa yang dilakukan pada bagian perencanaan, apa yang dilakukan pada pelaksanaan, apa yang dilakukan pada pengamatan dan apa yang dilakukan pada refleksi, seperti terlihat berikut ini.

\section{SIKLUS 1}

\section{Rencana Tindakan I}

Hasil yang didapat dari kegiatan perencanaan meliputi:

a. Menyusun rancangan tindakan selanjutnya penelitian lengkap dengan Rencana Pelaksanaan
Pembelajaran (RPP) yang akan dilaksanakan dengan Audio-Visual Berdasar hasil awal kemampuan siswa kelas 8 yang tertera pada latar belakang, peneliti merencanakan kegiatan yang lebih intensif seperti berkonsultasi dengan teman-teman guru dan kepala sekolah tentang persiapan pelaksanaan pembelajaran menggunakan tehnik Audio-Visual.

b. Menentukan waktu pelaksanaan, yang menyangkut hari, tanggal, sesuai dengan jadwal penelitian yaitu pada minggu ke 2 bulan oktober.

c. Meminta teman-teman guru bidang studi sejenis dan kepala sekolah sebagai mitra kesejawatan dalam pelaksanaan pembelajaran Audio-Visual yang sudah direncanakan. Hasilnya adalah kesiapan teman-teman guru untuk ikut melaksanakan supervisi kunjungan kelas dalam mengamati kekurangan yang ada.

d. Menyusun format pengecekan yang berhubungan dengan pembelajaran Audio-Visual.

e. Teman guru yang diminta mengamati pembelajaran diupayakan pembekalan tentang model pembelajaran ini dengan:

1) Supervisor diberitahu terlebih dahulu dan mengetahui metode pembelajaran yang menggunakan Audio-Visual dan kehadirannya di kelas bukan mencari kesalahan, tetapi untuk kepentingan bersama yaitu memperbaiki pembelajaran. 
2) Supervisor telah diberitahu untuk lebih memahami tentang prinsip-prinsip supervisi sehingga tidak lagi cenderung instruktif dan lebih bersahabat dengan prinsip kesejawatan.

3) Dalam pelaksanaan supervisi, supervisor diharapkan menunjukkan rasa kesejawatan yang akrab dan mau menilai kebenaran yang ada.

f. Peneliti memberikan penjelasan pada siswa bahwa kehadiran supervisor ke kelas bukan untuk mencari kesalahan atau kelemahan guru dalam pembelajaran, tapi untuk meningkatkan kemampuan siswa menguasai ilmu.

g. Merencanakan bahan pelajaran dan merumuskan tujuan. Menentukan bahan pelajaran, dengan cara menyesuaikan dengan silabus yang berlaku dan penjabarannya dengan cukup baik.

h. Memilih dan mengorganisaasikan materi, media, dan sumber belajar. Pada siklus pertama ini, peneliti mengorganisasikan materi pembelajaran dengan baik. Urutan penyampaiannya dari yang mudah ke yang sulit, cakupan materi cukup bermakna bagi siswa, menentukan alat bantu mengajar. Sedangkan dalam penentuan sumber belajar sudah disesuaikan dengan tujuan, materi pembelajaran dan tingkat perkembangan peserta didik.

i. Merancang skenario pembelajaran.

j. Skenario pembelajaran disesuikan dengan tujuan, materi dan

\begin{abstract}
tingkat perkembangan siswa, diupayakan variasi dalam penyampaian. Susunan dan langkah-langkah pembelajaran sudah disesuaikan dengan tujuan, materi, tingkat perkembangan siswa, waktu yang tersedia, sistematiknya adalah menaruh siswa dalam posisi sentral, mengikuti perubahan strategi pendidikan dari pengajaran ke pembelajaran sesuai Permen Diknas No. 41 Tahun 2007 dan menyesuaikan dengan model pembelajaran Audio-Visual.
\end{abstract}

\section{Pelaksanaan Tindakan I}

a. Pengelolaan Kelas

Mengelola kelas dengan persiapan yang matang, mengajar materi dengan benar sesuai model pembelajaran Audio-Visual.

b. Alat Penilaian

Pembahasan dan jenis penilaian, terlampir di RPP berikut format penilaian.

c. Penampilan

Penampilan secara umum, peneliti berpakaian rapi, menggunakan bahasa yang santun, menuntun siswa semaksimal mungkin dengan penggunaan metode pembelajaran Audio-Visual. Peneliti mengupayakan strategi agar mudah mengamati siswa yang sedang belajar. Setelah pembelajaran selesai dilakukan, dilanjutkan dengan mengadakan pertemuan dengan guru yang mengawasi 
proses pembelajaran untuk mendiskusikan hasil pengamatan yang dilakukan.

d. Dari diskusi dengan guru, terungkap bahwa:

1) Pembelajaran yang dilakukan belum maksimal, karena peneliti baru pertamakali mencoba metode ini.

2) Siswa-siswa memang belum aktif menerima pelajaran dan memberi tanggapan, ini sesuai dengan tujuan metode Audio-Visual.

3) Peneliti mengusulkan agar guru yang mengamati mau kembali dan bersedia mengamati kembali pada kesempatan di siklus II.

4) Untuk sementara, peneliti belum yakin bahwa pelaksanaan supervisi kunjungan kelas akan membantu meningkatkan kemampuan siswa, tetapi menurut pemikiran pengamat, cara yang dilakukan peneliti cukup mampu mendorong meningkatkan kreativitas dan prestasi belajar.

5) Penyampaian pengamat pada peneliti dapat disampaikan sebagai berikut: Perlu pengelolaan ruangan, waktu, dan fasilitas belajar yang lebih baik.

Dalam mengelola ruang kelas, waktu serta fasilitas belajar, dapat dipaparkan sebagai berikut:
- Peneliti menyediakan alat bantu/media pembelajaran.

- Peneliti kurang memperhatikan

kebersihan papan tulis, kebersihan seragam siswa, dalam hal lain yang berguna untuk menumbuhkan motivasi belajar dan disiplin siswa.

- Peneliti belum begitu baik dalam waktu. Memulai pelajaran tidak tepat waktu akibat hal-hal tertentu.

\section{Observasi/Pengamatan}

Pengamatan yang dilakukan sangat bervariasi. Penulis menggunakan guru teman sejawat untuk ikut masuk kelas mengamati kebenaran pelaksanaan pembelajaran yang menggunakan model AudioVisual. Data yang diperoleh dari kegiatan observasi yang dilakukan guru akan sangat berpengaruh terhadap kemajuan peneliti dalam menerapkan model pembelajaran Audio-Visual mengingat semua kelemahan peneliti akan teramati dengan baik. Apabila peulis hubungkan dengan yang disebut variabel penyela atau variabel intervening dimana ada hal-hal tertentu yang bisa mempengaruhi hubungan antara variabel bebas yaitu model pembelajaran Audio-Visual dengan variabel terikat yaitu pretasi belajar. Hal tertentu yang dibicarakan adalah kebenaran pelaksanaan model 
pembelajaran Audio-Visual. Apabila pelaksanaannya tidak benar sudah tentu akan berpengaruh terhadap hasil belajar.

Pengamatan oleh teman sejawat seperti yang dipaparkan di atas sangat perlu dilakukan demi keberhasilan peningkatan mutu dan kebenaran pembelajaran model Audio-Visual. Hal tersebut penulis lakukan demi adanya upaya inovasi agar tulisan ilmiah ini lebih berdaya guna dan berhasil guna.

Selain pengamatan yang dilakukan oleh teman sejawat, upaya lain yang penulis lakukan adalah menyuruh salah satu siswa yang pandai untuk mengecek apakah pelaksanaan pembelajaran AudioVisual di kelas sudah berjalan sesuai harapan atau belum. Baik guru yang mengamati, maupun siswa yang disuruh mengamati kegiatan temantemannya, sebelumnya sudah dipanggil ke kantor dan diberi penjelasan tentang kebenaran pelaksanaan pembelajaran AudioVisual yang menuntut kreativitas; penemuan sendiri oleh siswa; penekanan pada kegiatan intelektual; memproses pengalaman belajar menjadi sesuatu yang bermakna dalam kehidupan nyata; membiasakan siswa lebih produktif, analitis, kritis; penggunaan metode, teknik, dan strategi yang memungkinkan siswa mencari dan menemukan jawaban sendiri secara optimal. Selain itu, model ini menuntut kemampuan pemecahan masalah untuk peningkatan kepuasan intelektual, mempertajam proses ingatan untuk penguasan lebih lama, pembelajaran lebih terpusat pada siswa, pengembangan konsep diri dan bakat akademik, menghindarkan diri dari belajar dengan hafalan, menumbuhkan kemampuan mengasimilasi dan mengakomodasi informasi. Langkah-langkah pembelajarannya adalah: a) merumuskan pertanyaan untuk dapat melakukan penelitian, b) mencek apakah hasil pengamatan siswa dapat menjawab pertanyaan-pertanyaan, c) pengumpulan data/informasi, d) menganalisis informasi, e) membuat simpulan-simpulan berdasar hasil analisis informasi. Dari semua pengertian di atas, penulis sudah menyiapkan instrumen untuk ketepatan pelaksanaan yang dibawa oleh guru dan siswa yang mengamati proses pembelajaran.

\section{Refleksi Siklus I}

Sebelum memulai refleksi, ada baiknya melihat pendapat para pakar pendidikan tentang apa yang dimaksud dengan refleksi. Pendapat ini akan merupakan panduan terhadap cara atau hal-hal yang perlu dalam menulis refleksi. Refleksi merupakan kajian secara menyeluruh tindakan yang telah dilakukan berdasarkan data yang telah terkumpul, kemudian dilakukan evaluasi guna menyempurnakan tindakan. Refleksi menyangkut analisis, sintesis, dan penilaian terhadap hasil pengamatan atas tindakan yang dilakukan (Hopkin, 
1993 dalam Suharsimi Arikunto,

Suhardjono, Supardi, 2006: 80).

a. Analisis kuantitatif prestasi belajar siswa siklus I

Tabel 3. Prestasi belajar siswa siklus I

\begin{tabular}{|l|c|c|c|}
\hline \multirow{2}{*}{ SISWA } & \multirow{2}{*}{ IR } & \multicolumn{2}{|c|}{ SIKLUS } \\
\cline { 3 - 4 } & & S1 & S2 \\
\hline Ainur Robi Sahlan & 5.5 & 6 & 7 \\
\hline Alfan Febrian P. & 5 & 5 & 7 \\
\hline Ahmad Awali & 4.5 & 6 & 7 \\
\hline Amanda Dwi S. & 5.5 & 6 & 7 \\
\hline Auliawati & 4 & 6 & 7 \\
\hline Didik Hendriansyah & 4,5 & 5 & 7 \\
\hline Dimas Ar Rizky A. & 4.5 & 5 & 7 \\
\hline Debi Mayasari & 5 & 6 & 7 \\
\hline Haris Nugraha & 4.5 & 5 & 6 \\
\hline Iqbal Izzuwar & 4,5 & 5 & 7 \\
\hline Ika Avriliasari & 5 & 5 & 7 \\
\hline Moch. Hendra S. & 5 & 6 & 7 \\
\hline Moch. Syah Reza M. & 4,5 & 5 & 6 \\
\hline Marshenda R. K. Z. & 4,5 & 5 & 7 \\
\hline Melkior Ricardo D. & 5 & 6 & 7 \\
\hline Rifky Dwi Arvianto & 4,5 & 6 & 7 \\
\hline Septian Putra Fajar & 4,5 & 6 & 7 \\
\hline Setian Bayu Dwi B. & 4 & 6 & 7 \\
\hline Triana Wahyu A. & 4 & 5 & 7 \\
\hline Vira Amelia Jeny L. & 4 & 6 & 7 \\
\hline Ahmad Fauzi Rizca & 4 & 6 & 6 \\
\hline Adimas Trivaldi A. & 4,5 & 6 & 7 \\
\hline Rizky Nur Seftian & 4 & 5 & 7 \\
\hline Eren Kartika Putri & 4 & 5 & 7 \\
\hline Lisa Oktaviani & 4 & 5 & 7 \\
\hline Friska Dwi Olivia & 4 & 6 & 7 \\
\hline Yoga Dwi Prastyo & 5 & 5 & 7 \\
\hline & $\mathbf{1 2 2}$ & $\mathbf{1 5 4}$ & $\mathbf{1 8 7}$ \\
\hline
\end{tabular}

Berdasarkan data yang ditunjukkan pada tabel diatas bahwa nilai dari pre-test dan nilai post-test yang dikumpulkan oleh siswa kelas 8 SMPN 2 Dawarblandong pada siklus I dapat dihitung dengan cara sebagai berikut:

1) Nilai Rata-rata Pre-test $=\frac{X 0}{N}$

$$
=\frac{122}{27}=4,5
$$

2) Nilai Rata-rata Sesi $1=\frac{X 1}{N}$

$$
=\frac{154}{27}=5,7
$$

3) Nilai Rata-rata Sesi $2=\frac{X 2}{N}$

$$
=\frac{187}{27}=6,9
$$

Nilai total Rata-rata pada siklus pertama adalah:

$$
\frac{X 1+X 2}{N}=\frac{5,7+6,9}{2}=\frac{12,6}{2}=6,3
$$

b. Penyajian dalam bentuk grafik/histogram pada siklus I

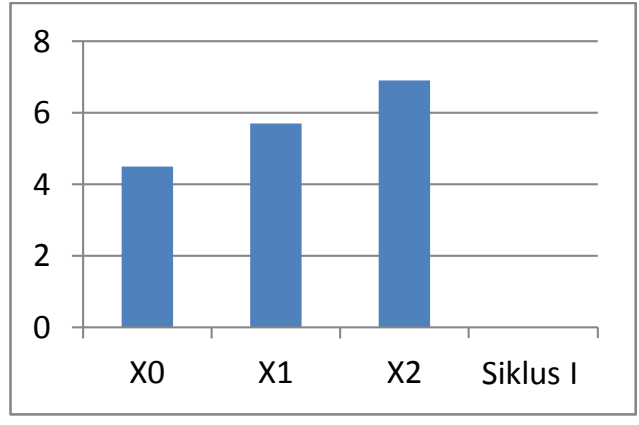

Untuk rekapitulasi hasil penelitian ini akan disampaikan sekaligus pada akhir analisis refleksi siklus II. Untuk hasil analisis pengamatan guru dan pengamatan siswa terhadap kebenaran pelaksanaan pembelajaran AudioVisual. Untuk kedua hasil pengataman tersebut dapat disampaikan sebagai berikut: 1) pengamatan oleh guru berupa catatan kesalahan peneliti pada saat melaksanakan proses pembelajaran Audio-Visual, hal ini menjadi masukan yang sangat berharga untuk perbaikan pada siklus 
selanjutnya, untuk hal ini lebih lengkapnya dapat dilihat pada pembahasan. 2) untuk pengamatan yang dilakukan oleh kepala sekolah yang ada pada lampiran 6, sudah terlihat tim yang mampu, tim yang belum mampu, sudah jelas menunjukkan keaktifan, keuletan, kreativitas, mencari hal-hal penting yang ditugaskan, menunjukkan kemampuan aktivitas, kritis, betul siswa yang giat belajar dan bukan guru yang giat mengajar, kemampuan menunjukkan konsep diri, kecepatan menanggapi tuntutan, kemampuan menelorkan kesimpulan-kesimpulan. Jumlah semua skor siswa pada pre-tes adalah 122, dan pada jumlah skor pada sesi 1 adalah 154, sedangkann skor pada sesi 2 adalah 187, setelah dirata-ratakan maka skor yang diperoleh adalah 4,5 untuk nilai pretest, 5,7 untuk nilai sesi 1 , dan 6,9 untuk nilai sesi 2 dari analisis yang dibuat, dapat diambil simpulan bahwa hasil yang didapat belum menunjukkan keberhasilan pembelajaran Audio-Visual yang dilakukan guru.

\section{SIKLUS II}

\section{Perencanaan}

Melihat semua hasil yang didapat pada siklus I, maka untuk perencanaan pelaksanaan penelitian di siklus II ini ada beberapa hal yang perlu dilakukan yaitu:

a. Peneliti merencanakan kembali jadwal untuk melakukan pembelajaran di kelas dengan melihat jadwal penelitian pada Bab III dan waktu dalam kalender pendidikan. Hasil dari refleksi siklus I merupakan dasar dari pembuatan perencanaan di siklus II ini.

b. Menyusun rencana pelaksanaan pembelajaran yang baik sesuai model pembelajaran Audio-Visual serta membuat instrumen pengumpulan data yaitu tes prestasi belajar.

c. Merencanakan kunjungan kelas bersama-sama teman-teman observasi sebagai upaya inovasi. Untuk ini peneliti berkonsultasi minta kesediaannya untuk ikut dalam proses pembelajaran yang dilakukan. Inovasi ini dilakukan agar peneliti dapat berupaya lebih maksimal untuk melaksanakan pembelajaran yang lebih baik dan lebih berkualitas. Hasil konsultasi dengan teman sejawat adalah adanya kesiapan guru untuk ikut melakukan supervisi kunjungan kelas. Guru yang akan mengobservasi diberitahu bahwa penulis sudah sempat berkonsultasi dengan kepala sekolah dan beliau akan ikut berpartisipasi, masuk ke ruangan untuk bersama-sama melakukan supervisi. Hal ini diberitahukan pada guru dengan harapan agar guru yang akan mengobservasi bisa lebih siap lagi untuk melakukan supervisi yang lebih berkualitas, ini juga penulis lakukan sebagai tambahan inovasi.

d. Bersama guru merancang skenario penerapan pembelajaran dengan melihat kekurangan-kekurangan yang ada pada siklus I dengan 
mengidentifikasi hal-hal yang bisa dilakukan untuk peningkatan pembelajaran. Untuk hal ini, semua catatan tentang kekurangan yang ada di siklus I yang merupakan hasil refleksi disampaikan pada guru untuk dipelajari. Memberitahu guru apa-apa yang perlu dilaksanakan, apa saja yang siswa mesti kerjakan, cara penerapan metode Audio-Visual yang benar sesuai kebenaran teori yang disampaikan.

\section{Pelaksanaan Tindakan}

Pelaksanaan tindakan pada siklus II ini disampaikan sebagai berikut:

Pada hari yang sudah ditentukan sesuai jadwal, peneliti memulai tahap pelaksanaan tindakan dengan membawa semua persiapan yang sudah dibuat, Sesuai dengan perencanaan yang telah disusun dalam bentuk rancanngan pembelajaran dengan penerapan tehnik Audio-Visual, maka langkahlangkah pembelajaran untuk pemahamam wacana disusun dalam langkah-langkah sesuai dengan metode yang diterapkan dalam penelitian ini. Adapun langkahlangkahnya adalah sebagai berikut:

Langkah pertama, Video pertama dengan topic "I Want to Fly" diputarkan kepada siswa dengan memberikan beberapa brainstorming untuk meningkatkan keinginan minat belajar siswa. Setelah video tersebut diputarkan selama 2 kali, kemudian siswa disuruh untuk menjawab beberapa pertanyaan yang bersifat umum sesuai dengan video yang diputarkan. Kemudian penulis mangjak siswa untuk mebahas setiap jawaban dari setiap pertanyaan yang diberikan.

Setelah pembahasan itu selesai, kemudian video kedua dengan topik "How Do I Get To Nanjing Road" diputarkan selama 2 kali. Kemudian siswa disuruh menjawab pertanyaan yang diberikan oleh penyaji secara lisan namun pertanyaan yang diberikan kali ini lebih mendetail berhubungan dengan video yang diputarkan.

Langkah selajutnya, siswa diputarkan video dengan topik "Are You Busy and What A Fat Bird" selama dua kali. Setelah video tersebut selesai diputarkan, kemudian siswa diberikaan multiple choice test dan siswa diberikan kesempatan untuk menjawab pertanyaan tersebut.

Setelah semua jawaban siswa terkumpulkan, kemudian siswa diberiakan naskah dari video pertama sampai video terakhir, kemudian siswa disuruh untuk menampilkan (perform) setiap video yang diputarkan sebelumnya di depan kelas.

Langkah-langkah di atas merupakan intisari dari perlakuan yang diberikan kepada siswa untuk meningkatkan pemahamannya dalam mendengarkan bahasa inggris. sehingga, hasil belajar siswa dengan menggunakan tehnik Audio-Visual dapat diharapkan lebih memuaskan 
dan dapat meningkatkan kemampuan mendengarkan siswa.

Pada pertemuan kedua kegiatan belajar dilanjutkan dengan pembahasan topik baru. Dimana pada kegiatan ini siswa diputarkan 4 video yang berjudul "Sign language, How do I get Nanjing Road, Long Farewell and What Do You Do". Pada awal kegiatan siswa diputarkan dua video yang berjudul "Sign Language and How do I get Nanjing Road". Guru memberikan brainstorming kepada siswa untuk mengenalkan video tentang "Sign Language and How do I get Nanjing Road". Guru memberikan beberapa pertanyaan terkait video yang diputarkan sebagai rangsangan. Semua pertanyaan tersebut dibahas secara klasikal dan oral sehingga siswa terbawa pada situasi pembelajaran yang menyenangkan.

Kemudian Guru menyuruh siswa menonton video yang berjudul "Long Farewell and What Do You Do" secara mandiri dengan 10 item pertanyaan yang diberikan yang meliputi aspek menemukan ide umum, menemukan informasi tertentu, menemukan informasi rinci, dan arti kata. Test ini sekaligus sebagai tes untuk menentukan kemajuan siswa pada siklus tindakan pertama ini dan siswa diberikan waktu selama 15 menit.

Demikianlah langkah-langkah pembelajaran pada proses tindakan siklus kedua ini dengan menerapkan Tehnik Audio-Visual dalam waktu $4 \mathrm{x}$ 40 menit ( $2 \times$ pertemuan).

\section{Observasi/Penilaian}

Penilaian terhadap kebenaran pelaksanaan pembelajaran AudioVisual didahului dengan mencatat halhal penting seperti aktivitas belajar yang dilakukan pada saat peneliti melakukan tindakan. Dari catatancatatan yang cepat tersebut penulis mengetahui bagian mana yang mesti diperbaiki, dibagian mana diperlukan penekanan-penekanan, dibagian mananya perlu diberi saran-saran serta penguatan-penguatan. Di samping itu adanya guru yang mengamati proses pembelajaran akan sangat membantu untuk mengetahui lebih jelas kesalahan-kesalahan yang dilakukan selama pross pembelajaran. Guru yang mengamati mencatat juga kreativitas siswa, kemauan siswa untuk ikut berpartisipasi dalam pembelajaran, kontribusi diantara para siswa. Semua ini sudah terlaksana dengan baik. Pelaksanaan tes prestasi belajar akhirnya dilanjutkan minggu depannya karena setelah guru melakukan proses pembelajaran, waktu untuk memberikan tes tidak mencukupi sehingga dilaksanakan pada pertemuan selanjutnya. Hasil tes prestasi belajar siswa siklus II akan dibahas pada refleksi II.

\section{Refleksi Siklus II}

a. Analisis Kuantitatif untuk Perolehan Nilai Tes Prestasi Belajar Siklus II

Tabel 4. Hasil tindakan siklus II

\begin{tabular}{|l|c|c|c|}
\hline \multirow{2}{*}{ SISWA } & \multirow{2}{*}{ IR } & \multicolumn{2}{|c|}{ SIKLUS } \\
\cline { 3 - 4 } & & S3 & S4 \\
\hline Ainur Robi Sahlan & 5.5 & 8 & 8 \\
\hline
\end{tabular}




\begin{tabular}{|l|c|c|c|}
\hline \multirow{2}{*}{ SISWA } & \multirow{2}{*}{ IR } & \multicolumn{2}{|c|}{ SIKLUS } \\
\cline { 2 - 4 } & & S3 & S4 \\
\hline Alfan Febrian P. & 5 & 7 & 8 \\
\hline Ahmad Awali & 4.5 & 7 & 8 \\
\hline Amanda Dwi S. & 5.5 & 7 & 8 \\
\hline Auliawati & 4 & 8 & 9 \\
\hline Didik Hendriansyah & 4,5 & 7 & 8 \\
\hline Dimas Ar Rizky A. & 4.5 & 7 & 8 \\
\hline Debi Mayasari & 5 & 7 & 8 \\
\hline Haris Nugraha & 4.5 & 8 & 8 \\
\hline Iqbal Izzuwar & 4,5 & 7 & 8 \\
\hline Ika Avriliasari & 5 & 7 & 9 \\
\hline Moch. Hendra S. & 5 & 8 & 9 \\
\hline Moch. Syah Reza M. & 4,5 & 7 & 8 \\
\hline Marshenda R. K. Z. & 4,5 & 7 & 8 \\
\hline Melkior Ricardo D. & 5 & 8 & 9 \\
\hline Rifky Dwi Arvianto & 4,5 & 7 & 8 \\
\hline Septian Putra Fajar & 4,5 & 8 & 9 \\
\hline Setian Bayu Dwi B. & 4 & 7 & 8 \\
\hline Triana Wahyu A. & 4 & 8 & 9 \\
\hline Vira Amelia Jeny L. & 4 & 7 & 8 \\
\hline Ahmad Fauzi Rizca & 4 & 7 & 8 \\
\hline Adimas Trivaldi A. & 4,5 & 7 & 8 \\
\hline Rizky Nur Seftian & 4 & 8 & 8 \\
\hline Eren Kartika Putri & 4 & 7 & 8 \\
\hline Lisa Oktaviani & 4 & 7 & 8.5 \\
\hline Friska Dwi Olivia & 4 & 7 & 8 \\
\hline Yoga Dwi Prastyo & 5 & 7 & 8.5 \\
\hline Total & 122 & 203 & 224 \\
\hline
\end{tabular}

$$
=\frac{203}{27}=7,5
$$

3) Nilai Rata-rata Sesi $4=\frac{X 4}{N}$

$$
=\frac{224}{27}=8,3
$$

Nilai total Rata-rata pada siklus pertama adalah:

$$
\frac{X 3+X 4}{N}=\frac{7,5+8,3}{2}=\frac{15,8}{2}=7,9
$$

b. Penyajian dalam bentuk grafik/histogram pada siklus II:

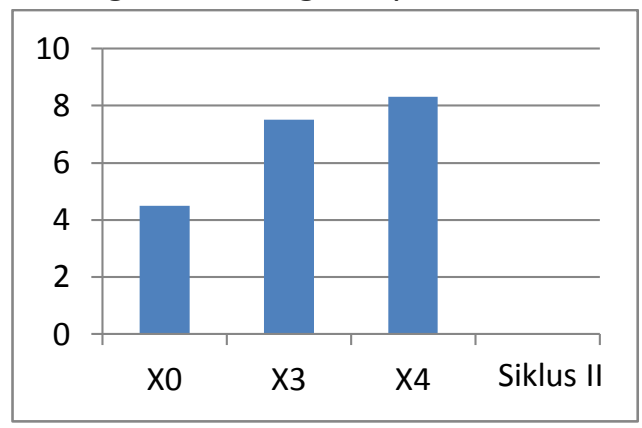

Tabel 5. Rekapitulasi Hasil Penelitian dari Siklus I sampai Siklus II

\begin{tabular}{|c|c|c|c|c|}
\hline No & \multicolumn{2}{|c|}{ Tindakan } & $\begin{array}{c}\text { Rata- } \\
\text { rata }\end{array}$ & $\begin{array}{c}\text { Total } \\
\text { Rata- } \\
\text { rata }\end{array}$ \\
\hline 1 & Pre-test & SO & 4.5 & X0 = 4.5 \\
\hline 2 & Siklus I & S1 & 5.7 & XI =6.3 \\
\hline & & S2 & 6.9 & \\
\hline 3 & Siklus II & S3 & 7.5 & XII $=7.9$ \\
\hline & & S4 & 8.3 & \\
\hline
\end{tabular}

\section{PEMBAHASAN}

Hal-hal yang perlu diperhatikan dalam pembahasan data kualitatif terhadap hasil pengamatan guru sejawat tentang pembelajaran AudioVisual adalah: kelemahan-kelemahan yang ada, kelebihan-kelebihan, perubahan-perubahan, kemajuankemajuan, efketivitas waktu, keaktifan yang dilakukan, konstruksi, kontribusi, 
diskripsi fakta, pengecekan validitas internal dan validitas eksternal, identifikasi masalah, faktor-faktor yang berpengaruh, cara-cara untuk memecahkan masalah, pertimbanganpertimbangan, perbandinganperbandingan, komentar-komentar, tanggapan-tanggapan, tambahan pengalaman, summary, pendapatpendapat, gambaran-gambaran, interpretasi/penafsiran-penafsiran, makna di belakang perbuatan, trianggulasi, hubungan antaraspek, klasifikasi, standar-standar penetapan nilai, alasan-alasan penggunan teknik tertentu, alasan penggunaan langkahlangkah tertentu, penggolonganpenggolongan, penggabunganpenggabungan, tabulasi, pemakaian, kriteria-kriteria, katagorisasi, pengertian-pengertian, hubungan antar kategori.

Dari hasil pengamatan teman sejawat disampaikan bahwa ada kelebihan-kelebihan yang disampaikan oleh pengamat yaitu bahwa peneliti sudah berpakaian rapi, menggunakan bahasa yang santun, menuntun siswa dengan baik. Hal ini menimbulkan interpretasi bahwa perjalanan penelitian sudah cukup baik. Kelemahan yang disampaikan perlu diberikan analisis yaitu penggunaan waktu yang belum efektif, konstruksi, kontribusi siswa belum maksimal, fakta ini akan dijadikan acuan kebenaran data, validasi, internal yang diambil dari informan di pertanggungjawabkan, validitas eksternal berupa acuan hukum digunakan teori-teori yang mendukung dan reliabilitas data penelitian ini dapat penulis yakini karena hal itu merupakan ketepatan peneliti memilih informan, yaitu teman sejawat. Faktor-faktor yang berpengaruh belum maksimalnya pembelajaran Audio-Visual pada siklus I ini adalah karena peneliti baru satu kali mencoba model ini. Cara pemecahan masalahnya adalah penyiapan RPP yang lebih baik, lebih berkualitas. Hal-hal yang lain seperti komentar, tambahan pengalaman, gambaran-gambaran keberhasilan penelitian akan terlihat pada hasil siklus selanjutnya. Demiian sediit hasil kualitatif atau kualitas dari pembelajaran dengan model AudioVisual.

\section{Pembahasan hasil yang diperoleh dari tes prestasi belajar siklus I}

Hasil tes prestasi belajar yang merupakan tes lisan dan multiple choice test memforsir siswa untuk betul-betul dapat memahami apa yang sudah dipelajari. Nilai ratarata siswa di siklus I sebesar 5,7 pada sesi pertama dan 6,9 pada sesi kedua menunjukkan bahwa siswa setelah menguasai materi yang diajarkan walaupun belum begitu sempurna. Hasil ini menunjukkan peningkatan kemampuan siswa menguasai mata pelajaran bahasa inggris khususnya dalam skill mendengarkan Apabila dibandingkan dengan nilai awal siswa sesuai data yang sudah disampaikan dalam analisis sebelumnya. 
Hasil tes prestasi belajar di siklus I telah menemukan efek utama bahwa penggunaan metode tertentu akan berpengaruh terhadap prestasi belajar siswa yang dalam hal ini adalah metode Audio-Visual. Hal ini sesuai dengan hasil meta analisis metode pembelajaran yang dilakukan oleh Soedomo, 1990 (dalam Puger, 2004) yang menyatakan bahwa metode pembelajaran yang diterapkan oleh seorang guru berpengaruh terhadap prestasi belajarnya.

Seperti telah diketahui bersama bahwasannya mata pelajaran Bahasa Inggris menitikberatkan pembelajaran pada aspek kognitif, afektif, dan psikomotor sebagai pedoman prilaku kehidupan sehari-hari siswa. Untuk penyelesaian kesulitan yang ada maka penggunaan metode ini dapat membantu siswa untuk berkreasi, bertindak aktif, bertukar pikiran, mengeluarkan pendapat, bertanya, berdiskusi, berargumentasi, bertukar informasi dan memecahkan masalah yang ada bersama dengan anggota kelompok diskusinya. Hal inilah yang membuat siswa berpikir lebih tajam, lebih kreatif dan kritis sehingga mampu untuk memecahkan masalah-masalah yang kompleks dan efek selanjutnya adalah para siswa akan dapat memahami dan meresapi mata pelajaran Bahasa Inggris lebih jauh.

Kendala yang masih tersisa yang perlu dibahas adalah prestasi belajar yang dicapai pada siklus I ini belum memenuhi harapan sesuai dengan tuntutan KKM mata pelajaran Bahasa Inggris di sekolah ini yaitu 7,5 Oleh karenanya upaya perbaikan lebih lanjut masih perlu diupayakan sehingga perlu dilakukan perencanaan yang lebih matang untuk siklus selanjutnya.

\section{Pembahasan Hasil yang Diperoleh} dari Siklus II

Hasil yang diperoleh dari tes prestasi belajar di siklus II menunjukkan bahwa kemampuan siswa dalam mengikuti pelajaran sudah cukup baik. Ini terbukti dari rata-rata nilai siswa mencapai 7,5 pada sesi 3 dan 8,3 pada sesi 4 Hasil ini menunjukkan bahwa metode Audio-Visual telah berhasil meningkatkan kemampuan siswa menempa ilmu sesuai harapan. Audio-Visual merupakan model yang cocok bagi siswa apabila guru menginginkan mereka memiliki kemampuan berkreasi, berargumentasi, mengeluarkan pendapat secara lugas, bertukar pikiran, berargumentasi, mengingat penggunaan metode ini adalah untuk memupuk kemampuan intelektual siswa, mendorong siswa untuk mampu menemukan sendiri, menempatkan siswa pada posisi sentral dan mengupayakan agar 
siswa tidak belajar dengan menghafal.

Hasil penelitian ini ternyata telah memberi efek utama bahwa model yang diterapkan dalam proses pembelajaran berpengaruh secara signifikan terhadap prestasi belajar siswa. Temuan ini membuktikan bahwa guru sudah tepat memilih metode dalam melaksanakan proses pembelajaran karena pemilihan metode merupakan hal yang tidak boleh dikesampingkan. Hal ini sejalan pula dengan temuantemuan peneliti lain seperti yang dilakukan oleh Inten (2004) dan Puger (2004) yang pada dasarnya menyatakan bahwa metode pembelajaran yang diterapkan berpengaruh terhadap prestasi belajar siswa.

Mata pelajaran Bahasa Inggris menitikberatkan kajiannya pada aspek kognitif, afektif dan psikomotor sebagai pedoman atas kemampuan siswa baik pikiran, prilaku maupun keter-Visual menempati tempat yang penting karena dapat mengaktifkan siswa secara maksimal. Dari nilai yang diperoleh siswa, lebih setengah siswa mendapat nilai 8,5, 13 siswa memperoleh nilai menengah yaitu 8. Dari perbandingan nilai ini sudah dapat diyakini bahwa prestasi belajar siswa dapat ditingkatkan dengan penggunaan metode Audio-Visual.

Melihat perbandingan nilai awal, nilai siklus I dan nilai siklus II, terjadi kenaikan yang signifikan, yaitu dari rata-rata nilai awal adalah 4,5 naik di siklus I menjadi 6,3 dan di siklus II naik menjadi 7,9 Kenaikan ini tidak bisa dipandang sebelah mata karena kenaikan nilai ini adalah dari upaya-upaya yang maksimal yang dilaksanakan peneliti demi peningkatan mutu pendidikan dan kemajuan pendidikan khususnya di SMPN 2 Dawarblandong.

\section{KESIMPULAN}

Dengan mengetahui bahwa pemicu rendahnya aktivitas belajar dan prestasi belajar ada pada faktorfaktor seperti metode yang digunakan guru, sehingga penggunaan atau penggantian metode konvensional menjadi metode-metode yang sifatnya konstruktivis sangat diperlukan, akibatnya peneliti mencoba model pembelajaran AudioVisual dalam upaya untuk dapat memecahkan permasalahan yang ada di sekolah.

Berdasar pada rendahnya aktivitas belajar dan prestasi belajar siswa yang disampaikan pada latar belakang masalah, penggunaan model pembelajaran

Audio-Visual diupayakan untuk dapat menyelesaikan tujuan penelitian ini yaitu untuk mengetahui peningkatan prestasi belajar siswa. Seberapa besar peningkatan yang dicapai sudah dipaparkan dengan jelas pada akhir analisis. Dari hasil penelitian yang disampaikan di Bab IV dan semua data yang telah disampaikan tersebut, 
tujuan penelitian yang disampaikan sudah dapat dicapai.

Untuk menjawab tujuan penelitian yaitu pencapaian kenaikan prestai belajar siswa dapat dilihat bukti-bukti yang sudah disampaikan.

1. Dari data awal hampir semua siswa mendapat nilai di bawah, kemudian pada siklus I menurun menjadi 8 siswa dan siklus II nilai semua siswa diatas standar yang ditentukan disekolah tersebut.

2. Dari rata-rata awal 4,5 naik menjadi 6,3 pada siklus I dan pada siklus II naik menjadi 7,9.

3. Dari data awal tidak ada siswa yang tuntas sedangkan pada siklus I menjadi lebih banyak yaitu 4 siswa dan pada siklus II semua siswa mencapai ketuntasan.

Dari semua data pendukung pembuktian pencapaian tujuan pembelajaran dapat disampaikan bahwa model Audio-Visual dapat memberi jawaban yang diharapkan sesuai tujuan penelitian ini. Semua ini dapat dicapai adalah akibat kesiapan dan kerja keras peneliti dari sejak pembuatan proposal, review hal-hal yang belum bagus bersama temanteman guru, penyusunan kisi-kisi dan instrumen penelitian, penggunaan sarana trianggulasi data sampai pada pelaksanaan penelitian yang maksimal.

\section{DAFTAR PUSTAKA}

Abdul. 2002. http://www.scribd.com/ doc/9037208/

Arikunto, Suharsimi; Suhardjono; Supardi. 2006. Penelitian
Tindakan Kelas. Jakarta: PT Bumi Aksara.

Badan Standar Nasional Pendidikan. 2007. Peraturan Menteri Pendidikan Nasional Republik Indonesia Nomor 41 Tahun 2007. Jakarta: BSNP.

Dahar, Ratna Wilis. 1989. Teori-Teori Belajar. Jakarta: Penerbit Erlangga.

Dimyati dan Mudjiono. 2001. Belajar dan Pembelajaran. Jakarta: Dirjen Dikti.

Djamarah, Syaful Bahri. 2002. Prestasi Belajar dan Kompetensi Guru. Surabaya: Usaha Nasional.

Fernandes, H.J.X. 1984. Testing and Measurement. Jakarta. National Education Planning, Evaluation and Curriculum Development.

Inten, I Gede. 2004. Pengaruh Model Pembelajaran dan Pengetahuan Awal Siswa Terhadap Prestasi Belajar PKn dan Sejarah pada Siswa Kelas II di SMU Laboratorium IKIP Negeri Singaraja. Tesis. Program Pascasarjana IKIP Negeri Singaraja.

Miles, Matthew, B. Dan A. Michael Hubberman. 1992. Analisis Data Kualitatif. Terjemahan Tjetjep Roheadi Rohidi. Jakarta: Penerbit Universitas Indonesia.

Puger, I Gusti Ngurah. 2004. Belajar Kooperatif. Diktat Perkuliahan Mahasiswa Unipas.

Sardiman, A.M. 1988. Interaksi dan Motivasi Belajar-Mengajar Pedoman bagi Guru dan Calon Guru. Jakarta: Rajawali Pers. 